\title{
Determinants of Customers’ Attitude towards Credit Card Usage: Lessons Learned from Academics in Sri Lanka
}

\author{
Mallika Appuhamilage Kumudini Sriyalatha \\ University of Sri Jayewardenepura Nugegoda, Western 10250, Sri Lanka \\ E-mail: kumuduni@sjp.ac.lk
}

Received: June 26, 2016 Accepted: July 11, 2016 Published: August 2, 2016

doi:10.5296/csbm.v3i2.9664 URL: http://dx.doi.org/10.5296/csbm.v3i2.9664

\begin{abstract}
This study examines the factors that influence the attitude of customers toward utilization of credit cards among academics at the University of Sri Jayewardenepura, Sri Lanka. 236 questionnaires were distributed through Google forms among academics in the Faculty of Management Studies and Commerce and 94 respondents have replied questionnaire back. Sample of the study is selected based on purposive sampling method.

The factors which are included in this study are availability of information, perceived usefulness, and characteristics of card issuers, general satisfaction and card use intension. Multiple regression analysis is used to determine the most contributory factor that best predict the attitude toward using credit cards. According to the results of the study the most influential variable on attitude towards credit card usage is card used intention followed by perceived usefulness and availability of information. The most influential variable is explained $47.4 \%$ of the variation in the attitude towards usage of credit cards and the adjusted $\mathrm{R}^{2}$ also indicates that the model has good fit: $52.5 \%$ variation in attitude towards credit card usage is explained by estimated regression equation.
\end{abstract}

Keywords: Attitude, Credit Card, Academics, Sri Lanka 


\section{Introduction}

According to the Central Bank of Sri Lanka, credit cards were introduced to Sri Lanka by Commercial Banks in 1989. At end of the third quarter 2015, there are 13 been licensed to engage in credit card business in Sri Lanka where 12 of them are Commercial Banks while 01 belongs to Finance Company (Payment Bulletin Central Bank of Sri Lanka-CBSL, 2015).

The demand of credit card can be seen from the report of payment bulletin which is published by the Central Bank of Sri Lanka. The payment bulletin of $3^{\text {rd }}$ quarter of 2015 recorded that credit cards are increasingly popular in Sri Lanka with a total of 11.2 million cards. The percentage change in usage of credit cards increased to 10.4 percent in $3^{\text {rd }}$ quarter 2015 from 8.1 percent in $3^{\text {rd }}$ quarter of previous year (Payment dBulletin CBSL, 2015). It is a quite big number since Sri Lanka is now rapidly moving towards cash-less society with the increase in credit card transactions. This is further supported by increased in the volume of electronic Point of Sales outlets (POS), reward schemes and incentives offered by credit card issuers.

Due to many reasons rapid increase in credit card usage in Sri Lanka has led to increase in competition among credit card issuers and features of the credit cards. Table 1 shows that recent trend of credit card usage in Sri Lanka.

Table 1. Total number of credit cards use in 2011-2015

\begin{tabular}{|l|l|l|l|l|l|}
\hline Description & $\begin{array}{l}2011-3^{\text {rd }} \\
\text { Quarter }\end{array}$ & $\begin{array}{l}2012-3^{\text {rdt }} \\
\text { Quarter }\end{array}$ & $\begin{array}{l}2013-3^{\text {rd }} \\
\text { Quarter }\end{array}$ & $\begin{array}{l}2014-3^{\text {rd }} \\
\text { Quarter }\end{array}$ & $\begin{array}{l}2015-3^{\text {rd }} \\
\text { Quarter }\end{array}$ \\
\hline $\begin{array}{l}\text { No. of Cards issued during } \\
\text { the period }\end{array}$ & 43230 & 45226 & 43912 & 47485 & 52424 \\
\hline $\begin{array}{l}\text { Total No. of Credit Cards } \\
\text { in use (As at end period) }\end{array}$ & 837662 & 935783 & 926949 & 997387 & 1115301 \\
\hline $\begin{array}{l}\text { Total Volume of } \\
\text { transactions (million) }\end{array}$ & 4.8 & 5.4 & 5.5 & 6.1 & 6.6 \\
\hline $\begin{array}{l}\text { Total Value of transactions } \\
\text { (Rs.billion) }\end{array}$ & 26.0 & 30.5 & 31.3 & 35.0 & 38.7 \\
\hline
\end{tabular}

Source: Payments Bulletin 2015, CBSL.

The above table indicates that the volume as well as value of credit card transactions has increased continuously, during the time period. This is a reflection of the popularity of the usage of credit cards usage among Sri Lankans.

Credit cards provide number of benefits to the users; specially access to financial resources. Consumers who use cash or cheques for particular transaction may be limited in the amount of funds they have. With cash, consumers are limited to the funds they have on hand. On the other hand merchants/ sellers may be reluctant to accept cheques for bigger transactions because of the risk of nonpayment/ default risk. Credit cards address solutions to both issues: they provide consumers with access to financial resources, and further they give merchants 
peace of mind about payment guarantees. People tend to adjust periodic gap between income and continuous consumption with access to credit. People receive their wages and salaries on the basis of weekly, biweekly or monthly. Consumer spending, however, has no specific time profile. Food on the table, sudden sickness of a family member or a broken-down vehicle should not allow waiting for the next pay day. Credits smooth the consumption of durable and nondurable goods by shorting the need to wait for paydays. Since customers do not have to go to automated teller machines regularly to withdraw cash spending becomes easier. They do not have to carry a lot of cash for their day to day requirements; both actions could reduce the risk of theft (Cayanan \& Ledesma, 2005). However, there are many adverse consequences like the misuse and abuse of using credit cards, exceeding from spending beyond what the budget allows to spend, high interest rates on due amounts.

Though there are many adverse consequences on credit cards usage it considers as a unique financial product that provides the carrier with access to a line of credit and serves as a transaction card. Analyzing the major determinants of credit card usage have become much more important in the context of increasing trend of credit card usage rather than the conventional credit schemes. The issuer of the card creates a revolving account and grants a line of credit to the consumer. Therefore, the user can borrow money for payment to a merchant or as a cash advance. Though this is the main objective of credit cards, currently people use credit cards with diverse perceptions. This paper provides comprehensible insights in identifying the attitude towards using a credit card while identifying the major determinants that can be affecting towards the usage of credit cards. Based on this background the researcher has developed the following research question to solve under the Sri Lankan context.

What are the factors that contribute to attitude towards credit card usage among academics in Sri Lanka?

This paper is organized into five sections, including this introduction. The second section presents the theoretical and empirical bases that support this research. The third section details the methodological procedures. The fourth section discusses the empirical results. The paper concludes with final considerations.

\section{Literature Review}

Credit cards have become a major instrument for carrying out and financing purchases among consumers. Furthermore, credit card debt has risen faster than household disposable income, and raising concern among policy-makers. Increased borrowing on credit cards to recover consumption spending is usually seen as a stimulating factor for the economy.

With the introduction of credit and debit cards has encourage the consumers' ability to maximize consumption decisions by providing them secure and quick access to all of their funds on deposit or a line of credit. Sellers also benefit by moving of less cash and cheque handling in the system as they have access to a large pool of customers with guaranteed payment. Cards also play vital role in e-commerce, with its inherent efficiencies. It is clear that credit cards play an important role in an economy. This process is explained by Moody's 
Report in 2016. They introduce economic cycle which explains the process of continued economic growth that is supported by credit cards. This shows that increased consumption due to increase in usage of credit cards lead to increased output and finally it facilitates to decline of unemployment in the economy. However, economists argue that high levels of debt may curtail spending in the future and hence ultimately results in slow economic growth (Moody’s Analytics, 2016).

In recent past credit card transactions in the world have been steadily raising, and with increased transactions comes increased debt. It has become a fact of life for most consumers and is a part of the consumer culture. As of 2011, seventy-seven percent of US adults owned at least one credit card, with a total of 1.4 billion cards in circulation. The average cardholder owned 7.7 cards and uses a credit card 119 times a year charging an average of \$88 per transaction or $\$ 10,500$ annually. By the end of 2011, with the unfolding of America's economic crisis, the average household credit card debt reached \$16,420 (Federal Reserve G.19 March, 2012).

Much of the previous research on the use of credit cards has focused on the difference between credit cards and other forms of payments on consumer spending. A common finding from this research is that when the decision to purchase has been made, the use of a credit card leads to more spending than cash or cheques (Feinberg, 1986; Hirschman, 1979; Inmanetal, 2009; Prelec \& Loewenstein, 1998; Rick et al., 2008). Brito \& Hartley (1995) show that credit cards provide liquidity service to the holders by avoiding opportunity cost of holding money. Further they reveal that credit cards become more attractive source of financing than the bank loan because of low transaction cost. The time and effort involved with taking loan from a financial institution is also high. This convenience allows many card holders to pay high interest on outstanding credit card balances. Canner \& Luckett (1992) indicate that this leads to a substantial growing of consumer's debt.

Zuroni \& Lim (2012) show that relationship between consumer's gender, education level and monthly income towards credit card practices. This study concludes that gender, monthly income, personal financial knowledge and attitude influencing the credit card practices among working adults in Malaysia. Meanwhile, they indicate that education level is the most significant factor among working adults.

Demographics factors such as age, income level play a vital role in making a choice and the use of credit cards as a convenience user. Studies suggest that there is a correlation between demographic factors and use of credit card. Kinsey (1981) indicates that the probability of having credit cards and the number was correlated highly with age and occupation. However, the study shows that there is a strong relationship between the place of residence, use of checking and savings accounts, and attitude towards credit. Number of studies indicates that a person is more likely to have more than one credit card and have a significant amount of debt with a positive attitude towards credit card use (Chen \& Devaney, 2001; Davies \& Lea, 1995; Hayhoe et al., 2000). Bowers (1979) conducted longitudinal study and shows that low income users of credit cards tend to use the cards for the installment feature rather than for service features such as convenience, safety, or identification. Further researchers identified that the 
installment feature of credit is important for low income consumer to permit purchases such as automobiles, furnishings, and other consumer durables.

Ahmed et al. (2009) examined the shift of Pakistani consumers towards the use of plastic money, with emphasis on credit cards. The study employed demographics variable and descriptive variables for analysis of general attitude about the use of credit cards and the factors contributing towards the selection of one particular credit card over the other. They found thata positive relationship between the income level of a person and his/her possession of the credit card. The profession of the person seems to play a very interesting role with their behavior towards credit cards. Moreover, the study shows that the convenience and security element that credit cards offer is most important for women.

Ismail et al. (2014) examined the factors influencing the attitude of bank customers in the context of the Malaysian banking system. The study employed the variable like knowledge, media awareness, perceptions, family influence and religious factors on attitudes towards credit card usage. The study shows that knowledge, media awareness, perceptions and family influence are instrumental in determining consumer attitudes toward credit card usage. In more detail, perceptions are ranked highest, followed by family influence and knowledge. Ismail et al. (2011) and Godwin (1998) indicated that there is a positive relationship between the general attitudes of consumers toward credit usage.

Dewri et al. (2016) investigated behavioral usage patterns of credit card users in the emerging economics and how the external factors are influencing the credit card users to use credit cards in their day-to-day life. The study found that there is a significant relationship among earnings and usage of credit limit; different age group has diverse tendency to use credit card and repayment attitudes; profession and usage behavior of credit card; e-repayment attitudes to pay bill by different age groups.

Norvilitis et al. (2006) examined factors that can causes and effects of credit-card debt in college students. The study was revealed that lack of financial knowledge, age, number of credit cards, delay of gratification, and attitudes toward credit-card use were related to debt. They also found that student attitude toward debt scale; gender and grade point average were not unique predictors of debt.

Hilgert \& Hogarth (2003) found that family influence and personal experience are the key means of learning to use credit effectively and the main sources of financial knowledge. Mansfield et al. (2003) show that parents, schools, peers and the media are all part of a young person's learning and socialization from birth to adulthood. All of these factors affect a young person's credit awareness as well as the advantages and problems involved with credit cards. Parents, schools, peers and media also play a major role in influencing the young adult's consumer behavior. Furthermore, Ismail et al. (2011) showed that parents have the greatest influence on a young person's credit card behavior.

The behavior and the attitude of the consumer towards the use and acceptability of credit cards differ for psychographic reasons. College students have favorable attitude toward credit cards. Female students who live in campus and working less than 20 hours have more 
favorable attitude regarding the credit cards (Xiao et al., 1995).

Atthaphol (2010) examined relationships between both Bangkok debt and credit card holder attitudes towards the intention to use credit cards. Results show that credit card attitudes to be directly related to the likelihood of credit card use. Further, study revealed those individuals who did not pay monthly balances in full, as well as those who had multiple cards, were shown to have more positive attitudes towards credit cards. Moreover, education level and the length of working experience are the most important variables that associate with the intention to use credit cards.

Maya \& Rofi (2011) showed that there was a positive attitude towards the use of credit cards among overall respondent, while the perceived usefulness had the highest contribution toward positive attitude to use of credit cards. Further the study pointed out that there was a strong intention to continue used credit cards, where the highest intention was the desire to finance routine expenses with credit cards. Additionally, researchers found that since respondents have been using credit cards wisely, the use of credit cards would provide supports and will not cause to financial problems in the future.

Ucal et al. (2011) examined effects of gender on credit card usage among university students in Turkey. They employed both parametric and nonparametric measures to measure the effects of gender on credit card usage. The study revealed that men tend to possess more credit cards than women. Nearly $60 \%$ of the women held only one credit card compared to $46 \%$ of the men. $36 \%$ of men versus $29 \%$ of the women had two cards. Further, they found that gender does affect credit card usage among Turkish university students although the effect is not consistent. At the same time the study showed that women tended to own fewer cards and spend less than their male counterparts. The most interesting result was revealed from this study was that more women than men felt it was prestigious to use credit cards.

Since credit card debts have caused several socioeconomic problems in many countries, the problem has received more attention of media, public policy makers and academics in recent years (e.g., Erdem, 2008). Shu \& Cheng (2012) examined the way to improve consumer attitudes toward using credit cards for online purchases. By manipulating message proximity and message source, they showed that authority-plus-contrast-plus-scarcity was the most persuasive combination.

Devlin, Worthington, \& Gerrard (2007) showed that credit card issuers must offer discount for promotion. In addition Durkin (1970-2000) indicated that issuers are essential to make available all relevant information regarding credit card at the time of issuing credit card. Gan, Maysami, \& Koh (2008) reported that people's lack of understanding or minimal information of industry is one of the major dilemmas in the credit card market. This lack of information affects adoption and usage of credit cards all time. Another group of researchers pointed outthat informational barrier impede the ability of credit card customers to obtain a competitive interest rate through search (Calem, Gordy, \& Mester, 2005).

Lee \& Kwon (2002) reported that credit cardholders have different motives in owning a credit card and so they differ in their payment practice. The authors categorized the 
cardholders into two types based on the mode of payment that they practice: the convenience users and the revolvers. Convenience users tend to use credit cards as an easy mode of payment and pay their balance typically in full on or before the due date stated in the account statement. They indicated that credit cards consider as a mode of financing as well as an open-ended, easily available credit source.

Substantial number of research studies has been done to identify the credit card usage among different customer groups. Using data from a structured survey, researches find that female Saudis are more likely than males to own the cards and attitude toward debt is a significant determinant of card ownership but not for usage behavior. Further they reveal that evaluation of card attributes is fairly positive among cardholders (Abdul-Muhminand Umar, 2007).

Kaynak \& Harcar (2001) examine consumer attitudes and intentions towards credit card ownership and usage in an advanced developing country. Variables use in the study are knowledge structures, beliefs, likes and dislikes, attitudes of credit card owners in the possession and use of credit cards.

Many research studies have been undertaken to examine the attitude towards credit card usage among employees, college students, adults and graduate students in different countries and universities in general (Abdul-Muhmin \& Umar, 2007; Blankson et al., 2012; Godfrey \& Clara, 2012; Norvilitis et al., 2006). There has not been research on positive or negative credit card usage pattern and attitudes toward credit card usage among university academics.

Though there is an increasing trend in number of credit cards users in Sri Lanka, there is a lack of recent research in Sri Lankan literature on this regard. Thus, the purpose of this study is to full fill this gap by identifying the factors that affect credit card usage among Sri Lankan consumers especially in University academics.

The present study focused on availability of information, perceived usefulness, characteristics of card issuers, general satisfaction and card use intention in predicting attitude towards credit card usage. To be more specific, this study examined the factors that affect attitudes towards credit card usage in university community by applying Theory of Planned Behavior model. It is based on the assumption that human beings are rational and can use information. Further it shows that intention to behave is the closest antecedent of a behavior. The stronger the person's intention to show a certain behavior, the more successful he/she is expected to do so. Thus the present study explores the relationship between selected variables and attitudes towards credit card usage among academics. Academics are an interesting group to study in the context of attitudes towards credit cards for a number of reasons:

- Academics are relatively homogeneous with regard to their income and to their necessary expenditures.

- Academics are unique from the other professions.

- Usage pattern of credit card among academics is different from general public. 
- Finally, lecturers who used credit cards actually if they want and are also involved directly with the process of payment on time; therefore, reliable and adequate data can be obtained for the purification of measurement scales and hypotheses testing.

\section{Research Model and the Hypotheses of the Study}

The dependent variable for this research is the customers' attitude toward utilization of credit cards. The independent variables are the factors that the researchers perceived as important in influencing attitude toward utilization of credit cards. Thus this study includes five independent variables which are availability of information, perceived usefulness, characteristics of card issuers, card use intension and general satisfaction. Major variables for this study were identified through reviewing the literature available on attitude towards credit card.

\section{Independent Variables}

Availability of information

Characteristics of card issuers

Perceived usefulness

Card use intension

General satisfaction

\section{Dependent Variable}

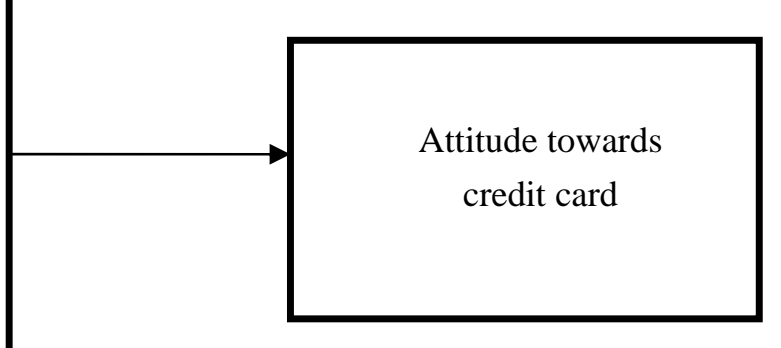

Figure 1. Research model of the study

Based on the literature reviewed and the researcher's prior insights the following hypotheses are postulated for this study.

H1. Customers' availability of information positively influence on their attitude toward the usage of credit cards.

H2. Customers' perceived usefulness positively affects their attitude toward the usage of credit cards.

H3. Customers' card use intention a positively influence on their attitude toward the usage of credit cards

H4. There is a significant relationship between issuers' characteristics and the customers' attitude toward the usage of credit cards.

H5. Customers' general satisfaction on credit cards has a significant influence on their attitude toward the usage of the cards. 


\section{Sample, Methodology and Results}

The survey was conducted among university academics in Sri Lanka namely; University of Sri Jayewardenepura. It has risen to be the largest public University in Sri Lanka in terms of the student population. In this study, we have employed the purposive sampling method to select the university, faculty and also respondent. The population of this study is the lecturers of the Faculty of Management Studies and Commerce. The Faculty of Management Studies and Commerce is the largest faculty in the university system in Sri Lanka and was founded in the 1960s and has a proud history and heritage as the Pioneering Faculty for Management Education in Sri Lanka. As the largest faculty in Management Studies and Commerce, it currently enrolls about 5,000 internal undergraduate students and 200 permanent lecturers. Based on this information, we decided to select respondent from the University of Sri Jayewardenepura for the study.

The survey mechanism was a structured questionnaire which included questions concerning credit card usage, demographic characteristics, and personal consumption attitudes and behaviors. A total of 200 questionnaires were distributed through Google form to the academics that belongs to the faculty of Management Studies and Commerce, in which only 94 were returned valid and completed. Likert scale question was created to capture their attitudes towards the usage of credit cards. Each of these questions was responded to on a five-point scale comprised of Strongly Agree, Agree, Neutral, Disagree, and Strongly Disagree.

We employed Cronbach's alpha (reliability coefficient) which is a measure of internal consistency and content validity of the questionnaire. In other words, how closely related a set of items are as a group. In social sciences, Cronbach's alpha 0.60 coefficients are acceptable. The reliability coefficient on average showed 0.763 (Table 2), and indicating that the items in this study have a relatively high internal consistency. In order to determine the relative contribution of availability of information, perceived usefulness, characteristics of card issuers, general satisfaction and card use intention in predicting attitude towards credit card usage, we employed multiple regression analyses with the above independent variables and attitude towards credit card usage as the dependent variable. Multiple regression analyses allow for a determination of which independent variable, and in what order, are important in explaining variance in the dependent variable. The beta weight associated with each independent variable provides a measure of its relative contribution. Reliability of total Items is 0.763 in Table 2 which shows its significance.

Table 2. Reliability statistics

\begin{tabular}{|l|l|}
\hline Cronbach's Alpha & N of Items \\
\hline 0.763 & 6 \\
\hline
\end{tabular}

As presented in Table 3, 51\% of the respondents were male, while $49 \%$ of the respondents 
were female. Out of 94 respondents, majority of the respondents belong to above 37 years. Most of respondents often use Visa credit cards (89.9\%) for their transactions. Normally card holders pay their credit card bill in full amount (62.8\%), while they use credit card twice in a week for the purchases (30.7\%). More than $50 \%$ of the respondents possessed one credit card. At the same time less than 5\% of the academics have four or five credit cards because of the cost of carrying multiple credit cards is high.

In the present study about $49 \%$ of the respondents reported owning one credit card whilst $24 \%$ owned at least two cards (Table 3). According to these results it is clear that the majority of the respondents own one card. This result was also consistent with the study conducted in Botswana by Pebe et al. (2012) where $41.5 \%$ of the respondents reported owning just one card whilst $6.5 \%$ and $1 \%$ owned two and three cards respectively. These findings are similar to findings of other developing middle-income countries. Turkey (Nasir, 2006) found that a large number of the respondents (31.9\%) owned only two cards. According to Gan et al. (2008) found that $65 \%$ of the respondents owned one to two cards in Singapore whilst in Saudi Arabia majority owned a maximum of two cards (Abdul-Muhmin \& Umar, 2007). The ownership of credit card in developing countries contrasts sharply with that of developed countries like the USA. For example, in a study conducted in USA by Robb (2011) found that the average number of credit cards owned exceeds four.

Credit card usage was identified based on how frequently the card is used in a month and how the outstanding balance is paid-whether in full, in partial or in minimum. As shown in Table 3, a total of 64 (68\%) respondents used their cards less frequently while 23 (24\%) used them more frequently. Furthermore, majority of the respondents (69\%) pay their outstanding balance on credit card in full whereas $23(24 \%)$ pay in partial. This result similar with the findings in Saudi Arabia (Abdul-Muhmin \& Umar, 2007) they found that the majority (68.3\%) of the respondents paid their monthly balances in full whilst $31.7 \%$ made partial payment.

Table 3. Demographic profile and credit card information of respondents

\begin{tabular}{|l|l|l|}
\hline Variable & Frequency & Percentage \\
\hline Gender & 48 & $51.06 \%$ \\
\hline Male & 46 & $48.94 \%$ \\
\hline Female & 46 \\
\hline Age Group & 3 & $03.20 \%$ \\
\hline $22-26$ & 31 & $33.00 \%$ \\
\hline $27-36$ & 34 & $36.20 \%$ \\
\hline $37-46$ & 25 & $26.60 \%$ \\
\hline $47-56$ & 1 & $01.10 \%$ \\
\hline Above 57 & \multicolumn{2}{|l}{} \\
\hline Marital Status & 75 & $79.80 \%$ \\
\hline Married & 19 & $20.20 \%$ \\
\hline Single & \multicolumn{2}{l}{} \\
\hline
\end{tabular}


No. of Children

\begin{tabular}{|l|l}
\hline None & 32 \\
\hline One & 27 \\
\hline Two & 26 \\
\hline Three & 9 \\
\hline Working Experience (Years) &
\end{tabular}

\begin{tabular}{|l|l|}
\hline 32 & $34.04 \%$ \\
\hline 27 & $28.73 \%$ \\
\hline 26 & $27.66 \%$ \\
\hline 9 & $09.57 \%$ \\
\hline
\end{tabular}

\begin{tabular}{|l|l|}
$1-5$ & \\
$6-10$ &
\end{tabular}

6-10 16

\begin{tabular}{|l|l}
\hline $11-15$ & 24 \\
\hline $16-20$ & 15
\end{tabular}

\begin{tabular}{|l|l}
\hline $16-20$ & 15
\end{tabular}

\begin{tabular}{|l|l}
\hline $21-25$ & 10 \\
\hline $26-30$ & 15
\end{tabular}

\begin{tabular}{|l|l}
\hline $26-30$ & 1 \\
\hline $30-35$ & 1
\end{tabular}

\begin{tabular}{l|l}
$30-35$ & 1 \\
\hline
\end{tabular}

\begin{tabular}{|l|l}
\hline above 36 & 2 \\
\hline
\end{tabular}

\begin{tabular}{|l|l}
\hline 25 & $26.90 \%$ \\
\hline 16 & $17.20 \%$
\end{tabular}

\begin{tabular}{l|l}
16 & $17.20 \%$ \\
\hline
\end{tabular}

\begin{tabular}{l|l}
16 & $17.20 \%$ \\
\hline 24 & $25.80 \%$ \\
\hline 15 & $16.10 \%$
\end{tabular}

\begin{tabular}{l|l}
\hline 15 & $16.10 \%$
\end{tabular}

Highest Level of Education

\begin{tabular}{|c|c|c|}
\hline Bachelor Degree & 13 & $13.80 \%$ \\
\hline Postgraduate Diploma & 1 & $01.10 \%$ \\
\hline Master Degree & 42 & $44.70 \%$ \\
\hline Doctoral Degree & 38 & $40.40 \%$ \\
\hline \multicolumn{3}{|c|}{ Monthly income (Gross-Rs) } \\
\hline Less than 50,000 & 11 & $11.70 \%$ \\
\hline $51,000-80,000$ & 14 & $14.90 \%$ \\
\hline $81,000-110,000$ & 24 & $25.50 \%$ \\
\hline $111000-130,000$ & 26 & $27.70 \%$ \\
\hline Above 130,000 & 19 & $20.20 \%$ \\
\hline \multicolumn{3}{|c|}{ No. of Credit Cards owned } \\
\hline One & 49 & $52.13 \%$ \\
\hline Two & 24 & $25.53 \%$ \\
\hline Three & 18 & $19.15 \%$ \\
\hline Four & 1 & $01.10 \%$ \\
\hline Five & 2 & $02.10 \%$ \\
\hline \multicolumn{3}{|c|}{ Monthly bill paying practices } \\
\hline Full payment & 65 & $69.15 \%$ \\
\hline Partial payment & 23 & $24.47 \%$ \\
\hline Minimum payment & 6 & $06.38 \%$ \\
\hline \multicolumn{3}{|c|}{ Credit card usage (monthly) } \\
\hline $1-2$ times & 64 & $68.08 \%$ \\
\hline 3-4 times & 7 & $07.45 \%$ \\
\hline 5-6 times & 23 & $24.47 \%$ \\
\hline
\end{tabular}

Source: Author compiled based on survey data. 
Table 4. Purposes of using credit cards

\begin{tabular}{|l|l|l|l|l|l|l|l|}
\hline \multirow{2}{*}{ Variable } & \multicolumn{7}{|l|}{ Number of Respondent as a percentage of total respondents } \\
\cline { 2 - 8 } & 1 & 2 & 3 & 4 & 5 & 6 & 7 \\
\hline Food & 36 & 15 & 12 & 10 & 9 & 6 & 12 \\
\hline Clothing & 25 & 22 & 18 & 8 & 10 & 9 & 8 \\
\hline Travel-local & 24 & 22 & 18 & 8 & 10 & 9 & 9 \\
\hline Travel-Foreign & 33 & 7 & 14 & 6 & 9 & 7 & 24 \\
\hline Fuel & 31 & 18 & 15 & 6 & 7 & 12 & 12 \\
\hline Medical & 30 & 20 & 14 & 9 & 6 & 13 & 9 \\
\hline Beauty Products & 17 & 8 & 3 & 13 & 3 & 19 & 38 \\
\hline Furniture & 12 & 22 & 13 & 9 & 10 & 16 & 19 \\
\hline Utilities & 23 & 17 & 12 & 6 & 11 & 9 & 22 \\
\hline Education-Local & 20 & 14 & 5 & 6 & 8 & 17 & 30 \\
\hline Education-Foreign & 27 & 14 & 5 & 8 & 11 & 13 & 22 \\
\hline Cash Advances & 16 & 4 & 10 & 7 & 2 & 16 & 44 \\
\hline Insurance & 21 & 16 & 10 & 8 & 5 & 10 & 32 \\
\hline Entertainment & 14 & 12 & 15 & 14 & 9 & 9 & 27 \\
\hline Books-Local & 17 & 23 & 19 & 3 & 9 & 11 & 19 \\
\hline Books-Foreign & 23 & 20 & 17 & 5 & 3 & 15 & 18 \\
\hline $1=$ most and 7 = Least for credit card expenditures & & & & \\
\hline
\end{tabular}

Source: Author compiled based on survey data.

We asked from respondents to rank their preferences (1-7) according to their purposes of using credit cards. Table 4 presents the types of commodities and services purchased by using credit cards. The most frequent spending made with credit cards was on food. Out of 78 total respondent, 28 (36\%) ranked food as first rank. In addition, clothing, foreign travel, fuel and medical are among the top commodities and services purchased using credit cards. Beauty product and entertainment are among the least commodities purchased using credit cards. Majority of the respondents do not use credit cards to get cash advance due to high interest rate. Foods and clothing are very popular among respondent because of discounts and special rate for those items with paying credit cards.

Table 5. Respondents view regarding credit card usage

\begin{tabular}{|l|l|l|}
\hline \multicolumn{3}{|l|}{ Do you advice another person to use a credit card? } \\
\hline Yes & 74 & $78.70 \%$ \\
\hline No & 20 & $21.30 \%$ \\
\hline
\end{tabular}

Academics appeared to be generally satisfied with the use of their credit cards even though they have different views regarding credit card practices. Certain practices by the credit card issuer 
companies are negatively viewed by the respondents. On the whole, credit card users appeared to believe that credit cards are useful, and that consumers are better off with credit cards than without them.

Further the evidence from the study revealed that majority of the respondents did not suggest negative views if credit cards arose from adverse personal experiences. In fact respondents' opinions about their own relationship with their current card issuers are much more agreeable than their opinions about the relations of consumers in general. $73 \%$ respondent of credit card holders conveyed their general satisfaction for dealings with their card companies, that their card companies treat them fairly, and that it is easy to get another card if they are not treated fairly. $61 \%$ trust that their own card companies would keep their personal information confidential.

Table 6. Model summary

\begin{tabular}{|l|l|l|l|l|}
\hline Model & R & R Square & Adjusted R Square & Durbin-Watson \\
\hline 1 & $0.767^{\mathrm{a}}$ & 0.544 & 0.525 & 1.759 \\
\hline
\end{tabular}

The result from model (1) in Table 6 presented above shows that the model is well behaved. The level of explanation of attitude towards credit card usage by availability of information, perceived usefulness, characteristics of card issuers, general satisfaction and card use intention is high as represented by the high value of coefficient of determination $\left(\mathrm{R}^{2}\right)$. The adjusted $\mathrm{R}^{2}$ also indicates that the model has good fit: $52.5 \%$ variation in attitude towards credit card usage is explained by estimated regression equation.

Table 7. Regression results

\begin{tabular}{|l|l|l|l|l|l|}
\hline \multirow{2}{*}{ Model } & \multicolumn{2}{|l|}{ Unstandardized Coefficients } & $\begin{array}{l}\text { Standardized } \\
\text { Coefficients }\end{array}$ & T statistic & $\begin{array}{l}\text { Significant } \\
\text { Level }\end{array}$ \\
\cline { 2 - 6 } & $\mathrm{B}$ & Std. Error & Beta & & \\
\hline Constant & 4.184 & 4.652 & & 0.899 & 0.372 \\
\hline Availability of Information & 0.179 & 0.096 & 0.177 & 1.870 & 0.066 \\
\hline Perceived Usefulness & 0.178 & 0.073 & 0.241 & 2.445 & 0.017 \\
\hline Characteristics of card Issuers & 0.012 & 0.133 & 0.009 & 0.091 & 0.928 \\
\hline General Satisfaction & 0.172 & 0.132 & 0.136 & 1.301 & 0.197 \\
\hline Card use Intention & 0.599 & 0.127 & 0.474 & 4.726 & 0.000 \\
\hline
\end{tabular}

Analysis of model (1) in Table 7 indicates that linear relation consisting of positive relationship between attitude towards credit card usage and its explanatory variables. The favorable card features (like lower interest rates and annual fee) operationally act as an important sign to encourage card usage and influence attitude toward credit card. Availability 
of information, perceived usefulness, and card use intention are statistically significant, characteristics of card issuers and general satisfaction are statistically insignificant even at $10 \%$.

Specifically, the predictive power of the independent variable is explained by the relevant beta value of the predictive variables. The most influential variable on attitude towards credit card usage is card used intention. This indicates that $47.4 \%$ of the variation in the attitude towards usage credit cards is explained by card use intention. Majority of the respondent agreed that credit cards facilitated for foreign purchases and it is safe and easy payment method than other methods. Not only the easy payment method it provides an opportunity to purchase even though they do not have enough cash. Because of these reasons, this study was found that the most significant and unique variable as card use intention on attitude towards credit card usage.

The other factors in the order of their importance are; perceived usefulness with the standardized coefficient of beta (0.241) and availability of information with standardized coefficient of beta (0.177). Furthermore, the standardized coefficient of beta in between characteristics of issuers and attitude toward usage of credit card is 0.009 ( $p=0.928)$. This shows that characteristics of issuers do not have a significant influence on their attitude toward usage of credit cards. Similarly, general satisfaction and attitude toward usage of credit cards as presents in the Table 7 is $0.136(p=0.197)$. This result indicates that general satisfaction does not significantly affect their attitude toward usage of credit cards. Thus, these two hypotheses are failed to reject since the p-value is more than 0.05 while the other hypotheses are rejected at $5 \%$ level of significant.

Table 8. Summary of the results

\begin{tabular}{|l|l|}
\hline Hypotheses & $\begin{array}{l}\text { Rejected / } \\
\text { Accepted }\end{array}$ \\
\hline $\begin{array}{l}\text { H1 Customers' availability of information positively influence on their attitude toward the } \\
\text { usage of credit cards. }\end{array}$ & Accepted \\
\hline $\begin{array}{l}\text { H2 Customers' perceived usefulness s positively affects their attitude toward the usage of } \\
\text { credit cards. }\end{array}$ & Accepted \\
\hline $\begin{array}{l}\text { H3 Customers' card use intention a positively influence on their attitude toward the usage } \\
\text { of credit cards } \\
\text { attitude toward the usage of credit cards. }\end{array}$ & Accepted \\
\hline $\begin{array}{l}\text { H4 Customers' general satisfaction on credit cards has a significant influence on their } \\
\text { attitude toward the usage of the cards. }\end{array}$ & Rejected \\
\hline
\end{tabular}

\section{Conclusion}

This study examines the relationship and the influence of availability of information, 
perceived usefulness, characteristics of card issuers, general satisfaction and card use intension on attitude toward using credit card. The study was limited only to University of Sri Jayewardenepura, Sri Lanka. It is further limited to the academics of the faculty of Management Studies and Commerce. This therefore, makes it difficult to generalize the findings even though the respondents come from different education levels and income levels. According to the results of the study the most influential variable on attitude towards credit card usage is card used intention followed by perceived usefulness and availability of information. This is consistent with studies by Yahaya \& Haji-Othman (2014) and Maya \& Rofi (2011) that perceived ease of use and perceived usefulness of a credit card influences attitude towards usage of credit cards.

This study provides important implications toward practitioners and potential credit card users. First, card use intension is an important factor that should be considered by banks offering credit cards. Respondent mostly use credit cards to purchase day to day necessities and foreign purchases and they prefer these cards mostly for online purchases (Maya \& Rofi, 2011). Further, the results of this study suggest that perceived usefulness and availability of information regarding credit card have important influence on attitude towards credit card usage. This result is consistent with the findings of Durkin (1970-2000) and Calem, Gordy, \& Mester (2005). A number of methods can be utilized to increase the available information concerning credit cards. For instance, banks can provide more precise data with more transparency about interest rates charge by banks on late payment, registration fees, annual renewal fees, etc. And also banks can publish the latest information about credit cards, which should help to take decision regarding the credit card holders to in which manner they have to use their credit cards. The study revealed that majority of the respondents are been using credit cards intelligently (majority pay full payment-69\%); therefore, the use of credit card will not lead to serious financial problems or heavy debt burden (Maya \& Rofi, 2011).

\section{Managerial Implications}

From a managerial perspective, the results of this study provide useful insights into the credit card market in Sri Lanka. When we consider academics, they have common characteristics, like income, level of education, pattern of purchases from credit cards. Further, academics are relatively homogeneous with regard to their necessary expenditures. Using pattern of credit card among academics is different from general public. According to the revealed information on attitude towards credit card usage, academics appeared to be generally satisfied with the use of their credit cards even though they have different views regarding credit card practices. Certain practices by the credit card issuer companies are negatively viewed by the respondents. On the whole, credit card users appeared to believe that credit cards are useful, and that consumers are better off with credit cards than without them. Various credit terms, such as interest rates, annual membership fee, late payment charges and other finance charges were considered to be main focus of respondents for the required disclosures. It also indicated these terms as important for applying new credit card. Overall, respondents have been using credit cards wisely, therefore, in long term, the use of credit cards would provide benefits and will not cause financial problem for them. 
Knowing consumers' level of interest in using credit cards is important in shaping, and perhaps changing a bank's product portfolio. Therefore, it is recommended that product development should be based on the information taken from the customers. The study shows that the convenience and security element that credit cards offer is most important for respondent. For boost of credit card business, a very important role is played by the customer support service. Developing a competent and helpful customer support department can create a positive image of the bank. Arthur \& Dimitris (1994) found that security is an important feature in the selection criteria of credit cards. Security is in two senses, as protection against credit cards fraud or in the case of card lost/stolen.

\section{References}

Abdul-Muhmin, A. G., \& Umar, Y. A. (2007). Credit card ownership and usage behavior in Saudi Arabia: the impact of demographics and attitudes toward debt. Journal of Financial Services Marketing, 12(3), 219-234. http://dx.doi.org/10.1057/palgrave.fsm.4760074

Ahmed, A., Amanullah, A., \& Hamid, M. (2009). Consumer perception and attitude towards credit card usage: A study of Pakistani consumers. Journal of Comparative International Management, 12(1), 47-57.

Arthur, M., \& Dimitris, D. (1994). Credit and Charge Cards Selection Criteria in Greece. International Journal of Bank Marketing, 12(2), 36-44. http://dx.doi.org/10.1108/02652329410052964

Atthaphol, J. (2010). Credit card use among Bangkok cardholders: An exploration into credit card attitudes, Debt and strategy improvement. ABAC Journal, 30(3), 15-29.

Blankson, C., Paswan, A., \& Boakye, K. G. (2012). College students' consumption of credit cards. The International Journal of Bank Marketing, 30(7), 567-585. http://dx.doi.org/10.1108/02652321211274327

Bowers, J. (1979). Consumer credit use by low income consumers who have had a consumer education course: An exploratory study. The Journal of Consumer Affairs, 13(2), 340-341.

Brito, D. L., \& Hartley, P. (1995). Consumer Rationality and Credit Cards. Journal of Political Economy, 103(2), 400-433. http://dx.doi.org/10.1086/261988

Calem, P. S., Gordy, M. B., \& Mester, L. J. (2005). Switching Costs and Adverse Selection in the Market for Credit Cards: New Evidence. Working paper. http://dx.doi.org/10.2139/ssrn.796108

Canner, G. B., \& Luckett, C. A. (1992). Developments in the pricing of credit card services. Federal Reserve Bulletin, 78(9), 652-666.

Cayanan, A. S., \& Ledesma, C. C. (2005). An analysis of the credit card industry in the Philippines. In R. A. Rodriguez \& M. B. Albarracin (Eds.), Analysis of selected Philippine industries, 1, 177-229. Quezon City, Philippines: The University of the Philippines Press. 
Chien, Y. W., \& Devaney, S. A. (2001). The effects of credit attitude and socioeconomic factors on credit card and installment debt. Journal of Consumer Affairs, 35, 162-179. http://dx.doi.org/10.1111/j.1745-6606.2001.tb00107.x

Davies, E., \& Lea, S. E. G. (1995). Student attitudes to student debt. Journal of Economic Psychology, 16, 663-679. http://dx.doi.org/10.1016/0167-4870(96)80014-6

Devlin, J. F., Worthington, S., \& Gerrard, P. (2007). An analysis of main and subsidiary credit card holding and spending. International Journal of Bank Marketing, 25(2), 89-101. http://dx.doi.org/10.1108/02652320710728429

Dewri, L. V., Islam, R. M., \& Saha, N. K. (2016).Behavioral analysis of credit card users in a developing country: A case of Bangladesh. International Journal of Business and Management, 11(4), 299-313. http://dx.doi.org/10.5539/ijbm.v11n4p299

Durkin, T. A. (2000). Credit Cards: Use and Consumer Attitudes, 1970-2000. Federal Reserve Bulletin, 86, 623-634. [Online] Available: http://www.federalreserve.gov/pubs/bulletin/2000/0900lead.pdf

Erdem, C. (2008). Factors affecting the probability of credit card default and the intention of card use in Turkey. International Research Journal of Finance and Economics, 18, 159-171.

Federal Reserve. (2012). G 19 report 2012 March. [Online] Available: www.federalreserve.gov/releases/g19/Current/

Feinberg, R. A. (1986). Credit cards as spending facilitating stimuli: A conditioning interpretation. Journal of Consumer Research, 13, 348-356. http://dx.doi.org/10.1086/209074

Gan, L. L. Maysami, R. R.C., \& Koh, H. C. (2008). Singapore credit cardholders: ownership usage patterns and perceptions. Journal of Services Marketing, 22(4), 267-279. http://dx.doi.org/10.1108/08876040810881678

Godfrey, T., \& Clara, B. T. (2012). Credit card ownership and usage behaviour in Botswana. International Journal of Business Administration, 3(6).

Godwin, D. D. (1998). Household debt quintiles: Explaining changes 1983-1989. The Journal of Consumer Affairs, 369-393. http://dx.doi.org/10.1111/j.1745-6606.1998.tb00414.x

Hayhoe, C. R., Leach, L. J., Turner, P. R., Bruin, M. J., \& Lawrence, F. C. (2000). Differences in spending habits and credit use of college students. The Journal of Consumer Affairs, 34(1), 113-133. http://dx.doi.org/10.1111/j.1745-6606.2000.tb00087.x

Hilgert, M. A., \& Hogarth, J. M. (2003). Household financial management: The connection between knowledge and behavior. Federal Reserve Bulletin, pp. 309-322.

Hirschman, E. (1979). Differences in consumer purchase behavior by credit card payment system. Journal of Consumer Research, 6, 58-66. http://dx.doi.org/10.1086/208748

Inman, J. J., Russell, S. W., \& Ferraro, R. (2009). The interplay among category 
characteristics, customer characteristics, and customer activities on in-store decision making. Journal of Marketing, 73, 19-29. http://dx.doi.org/10.1509/jmkg.73.5.19

Ismail S., Amin, S., Shayeri, S. F., \& Hashim, N. (2014). Determinants of attitude towards credit card usage. Jurnal Pengurusan, 41, 145-154. http://dx.doi.org/10.17576/pengurusan-2014-41-13

Ismail, S., Serguieva, A., \& Singh, S. (2011). Integrative model to students' attitude to educational loan repayment: A structural modeling approach. Journal of International Education in Business, 4(2), 125-135. http://dx.doi.org/10.1108/18363261111189522

Jusoh, Z. M., \& Lin, L. Y. (2012). Personal financial knowledge and attitude towards credit card practices among corking adults in Malaysia. International Journal of Business and Social Science, 3(7), 176-185.

Kaynak, E., \& Harcar, T. (2001). Consumers' attitudes and intentions towards credit card usage in an advanced developing country. Journal of Financial Services Marketing, 6(1), 24-39. http://dx.doi.org/10.1057/palgrave.fsm.4770038

Kinsey, J. (1981). Determinants of credit card accounts: An application of Tobit analysis. Journal of consumer Research, 8(2), 172-182. http://dx.doi.org/10.1086/208853

Lee, J., \& Kwon, K. N. (2002). Consumers' use of credit cards: Store credit card usage as an alternative payment and financing medium. Journal of Consumer Affairs, 36(2), 239-262. http://dx.doi.org/10.1111/j.1745-6606.2002.tb00432.x

Mansfield, P. M., Pinto, M. B., \& Parente, D. H. (2003). Self-control and credit card use among college students. Psychological Report, 92, 1067-1078. http://dx.doi.org/10.2466/PR0.92.4.1067-1078

Maya, S., \& Rofi, R. (2011). Factors affecting the behavior of University community to use credit card. International Research Journal of Business Studies, 4(3), 217-228.

Moody's Analytics. (February 2016). The impact of electronic payments on economic growth, Economic \& consumer credit analytics. [Online] Available: https://usa.visa.com/dam/VCOM/download/visa-everywhere/global-impact/impact-of-electro nic-payments-on-economic-growth.pdf

Nasir, S. (2006). Consumer Behaviour of Credit Card Users in an Emerging Market. Paper presented at the 6th Global Conference on Business \& Economics held October 15-16, 2006 at Gutman Conference Center, USA.

Norvilities, J. M., Merwin, M. M., Osberg, T. M., Roehling, P. V., Young, P., \& Kamas, M. M. (2006). Personality factors, money attitudes, financial knowledge and credit card debt in college students. Journal of Applied Social Psychology, 36(6), 1395-1413. http://dx.doi.org/10.1111/j.0021-9029.2006.00065.x

Payment Bulletin Central Bank of Sri Lanka. (2015).

Pebe, M., Eze, U. C., Yeow, J. A., \& Li, K. P. (2012). Credit Card Use Patterns among 


\section{Macrothink}

Case Studies in Business and Management

ISSN 2333-3324

2016, Vol. 3, No. 2

Working Adult in Batswana. International Journal on Social Science Economics \& Art, 2(2), 81-88.

Prelec, D., \& Loewenstein, G. (1998). The Red and the black: mental accounting of savings and debt. Marketing Science, 17(1), 4-28. http://dx.doi.org/10.1287/mksc.17.1.4

Rick, S., Cryder, C., \& Loewenstein, G. (2008). Tightwads and spendthrifts. Journal of Consumer Research, 34(6), 767-782. http://dx.doi.org/10.1086/523285

Robb, C. A. (2011). Financial Knowledge and Credit Card Behaviour of College Students. Journal of Family and Economic Issues, 32(4), 690-698. http://dx.doi.org/10.1007/s10834-011-9259-y

Shu, W., \& Cheng, C. Y. (2012). How to improve consumer attitudes toward using credit cards online: An experimental study. Electronic Commerce Research and Applications, 11(4), 335-345. http://dx.doi.org/10.1016/j.elerap.2012.01.003

Ucal, M. O., Neil, M. L., \& Çankaya, S. (2011). Effects of gender on credit card usage among university students in Turkey. African Journal of Business Management, 5(22), 9023-9030. http://dx.doi.org/10.5897/AJBM11.1313

Xiao, J. J., Noring, F. E., \& Anderson, J. G. (1995). College students' attitudes toward credit cards. Journal of Consumer Studies and Home Economics, 19, 155-174. http://dx.doi.org/10.1111/j.1470-6431.1995.tb00540.x

Yahaya, S., \& Haji-Othman, Y. (2014). Determinants of attitude of customers towards usage of Islamic credit card: A Study of Graduate students of Kolej Universitiy Insaniah. European Journal of Business and Management, 6(32), 145-152.

\section{Copyright Disclaimer}

Copyright for this article is retained by the author(s), with first publication rights granted to the journal.

This is an open-access article distributed under the terms and conditions of the Creative Commons Attribution license (http://creativecommons.org/licenses/by/3.0/). 